\title{
HIGH-PERFORMANCE WORK SYSTEMS IN RUSSIAN AND INDIAN IT COMPANIES
}

\author{
E. K. ZAVYALOVA, D. G. KUCHEROV, V. S. TSYBOVA \\ Graduate School of Management, St. Petersburg State University, Russia
}

\begin{abstract}
High-performance work systems represent one of the key topics in contemporary strategic human resource management. This study aims to examine the high-performance work systems in the IT sector of two emerging markets, Russia and India. The research, based on a survey of 132 companies, indicates that there are differences in human resource management practices between Russian and Indian IT companies, which constitute high-involvement and highcommitment work systems. Furthermore, regression analysis reveals that these systems impact a firm's performance differently. The findings extend the literature on high-performance work systems in knowledge-intensive firms in emerging markets.
\end{abstract}

Keywords: high-performance work systems, high-performance work practices, performance, IT companies, knowledge-intensive firms.

JEL: M12, M54.

The empirical verification of the relationship between high performance work practices (HPWPs) and firm performance has been one of the key topics in the strategic human resource management (strategic HRM) literature for the past 25 years. The first largescale investigation was undertaken in [Huselid, 1995], which confirmed an impact of HPWPs on both intermediate employee outcomes (turnover and productivity) and corporate financial performance of large national US firms. At the present time, there is a considerable number of empirical studies on strategic HRM in developed markets (e.g.,
[Richard, Johnson, 2001; Harris, Ogbonna, 2001; Stavrou, Brewster, 2005]). Special attention is given here to [Lengnick-Hall et al., 2009] explaining contingency perspectives and fit, shifting from a focus on managing people to creating strategic contributions, elaborating HR system components and structure, expanding the scope of strategic HRM, achieving HR system implementation and execution, measuring outcomes of strategic HRM and evaluating methodological issues. The term high performance work system is used to explain the positive impact of HRM practices on organizational outcomes. Meanwhile, due to con-

Postal Address: 3, Volkhovskiy per., Graduate School of Management, St. Petersburg State University, St. Petersburg, 199004, Russia.

(CE. K. Zavyalova, D. G. Kucherov, V. S. Tsybova, 2020

https://doi.org/10.21638/spbu18.2020.205

PЖM 18 (2): 235-254 (2020) 
fusing definitions, unjustified assertions and weakness in research methods [Boxall, 2012, p. 170], HPWS is becoming a fuzzy phenomenon in which three concepts are loosely tied together: performance, systemic effects, and work practices of some kind [Boxall, Macky, 2007].

The present study follows the idea that bundles of HRM practices have an impact on the achievement of HRM objectives and firm performance [Hauff, Alewell, Hansen, 2014, p. 425]. At the same time, the composition of these practices will show contextual variations based primarily on institutional environment, including the national legal system and cultural foundations. We agree with the idea that HRM practices lead to multiple outcomes, and these outcomes can be achieved by multiple combinations of HRM practices [Delery, 1998]. For this reason, in our research we investigate the relationship between specific HRM practices and two firm-level outcomes.

The paper seeks to contribute to the debate in the field of strategic HRM in the following way. We focus on the IT sector of two emerging markets, Russia and India. IT is one of the fast-growing knowledge-intensive industries worldwide. In the new economy, IT plays a key role in creating, accumulating and disseminating knowledge to enhance the competitiveness of developed and developing countries. A number of studies show that the IT industry worldwide is quite sensitive to changes in social and economic environment. One of the key external factors affecting the outcomes of IT companies is the labor market, and particularly the deficiency of IT professionals. In these conditions the strategic goal of IT companies is to establish such HPWS that will provide an efficient recruitment, utilization and retention of employees.

Our research design is based on the assumption that IT companies both in Russia and India use HPWPs, which, in turn, contribute to organizational performance. Meanwhile, the combination of these practices for each country is different and conditioned by the institutional context. Thus, we stick with the bundling approach and agree with the idea that there may be a number of possible combinations or configurations of practices which will lead to high performance [Guest, 1997]. In other words, these combinations, rather than individual practices by themselves, yield major benefits [Delery, Gupta, 2016]. We make use of a well-known European quality standard "Investors in people" (IiP) applied in developed countries as a framework for the assessment of an HRM system in organizations by comparing it with the Russian and Indian IT companies' HRM systems. Additionally, we identify those HPWPs that impact performance of Russian and Indian IT companies.

Thus, we formulate the following research questions.

Research question 1. What types of HPWSs are used by Russian and Indian IT companies?

Research question 2. What is the relationship between HPWSs and performance of Russian and Indian IT companies?

The article is divided into four sections. We start with a theoretical background on HPWSs. The review of the IT industry development in Russia and India is done, and the previous studies of HRM practices in IT companies in Russia and India are considered. Next, we discuss the research methodology, including the data collection and measures. Then, we present the main results of our empirical study. Finally, we provide the discussion of the contribution of our findings.

\section{THEORETICAL BACKGROUND}

An HR system as such is an important strategic asset [Becker, Huselid, 2006]: it is a source of value creation in the subsequent HR outcomes with a high level of inimitability and immobility. The HR systems that enhance employee competencies, commitment and productivity are considered as HPWSs [Posthuma et al., 2013]. The idea of HPWSs is based on a bundle perspective where a set of interrelated, internally consistent and mutually supportive HRM practices could 
contribute to superior outcomes. Not all the configurations (bundles) of HRM are equally effective: some configurations are clearly better at enhancing different organizational outcomes. Bundles are specific combinations of HR practices which generate higher business performance, but these combinations will vary by organisational context [Richardson, Thompson, 1999]. Organizational outcomes could cover improvement in work attitudes (employee satisfaction, commitment, trust, motivation), behavior (employee turnover, absence), productivity and quality of services and products [Paauwe, Boselie, 2005]. "The logic in favour of bundling is straightforward... Since employee performance is a function of both ability and motivation, it makes sense to have practices aimed at enhancing both" [Dyer, Reeves, 1995, p. 657]. In the modern sense of the term, these practices are divided into three dimensions: skill enhancing, motivation enhancing and opportunity enhancing. Each group of practices has a particular impact on intellectual capital resources (human capital, social capital and organizational capital), hence indirectly being the source of a competitive advantage of the firm.

Different synergistic HRM practices construct specific HPWSs. [Walton, 1985] proposed the dichotomy of control and commitment HRM systems. Control and commitment are two distinct approaches in which employee attitudes and behaviors can be influenced [Arthur, 1994]. The goal of the control or high-performance HRM system is to "establish order, exercise control, and achieve efficiency in the application of the workforce" [Walton, 1985, p. 78]. This traditional system is associated with mass production. The main attributes of the control HRM system are high labour specialization, fixed task assignments, direct control, formal organizational structure, low level of employee participation in a decision-making process and giving specific training to employees [Walton, 1985; Arthur, 1994].

High commitment management is "a form of management which is aimed at eliciting a commitment so that behaviour is primarily self-regulated rather than controlled by sanctions and pressures external to the individual, and relations within the organization are based on high levels of trust" [Wood, 1996, p. 41]. Hence the commitment HRM system is aimed at finding the balance between employee interests and organizational goals. The main attributes of the commitment HRM system are flexible work design, comparatively high involvement of employees in a decision-making process, indirect supervision, informal organizational structure, job rotation, regular quality circles and giving general training to employees [Walton, 1985; Arthur, 1994].

Contemporary studies on strategic HRM [Armstrong, 2006; Edwards, Wright, 2001] distinguish one more system called a highinvolvement HRM system. In that system employees are perceived as partners of the company whose interests are respected and who have a voice on matters that concern them [Armstrong, 2006]. The core attributes of the high-involvement HRM system [Edwards, Wright, 2001] are schemes to promote employee discretion and autonomy such as formally designated teamworking, quality circles or problem-solving groups; systems of communication that allow for upward communication of employee suggestions as well as downward communication from management; and serious attention to developing employee skills [Becker, Huselid, 2006].

\subsection{Russian and Indian IT sector}

Knowledge-intensive companies are the organizations whose primary value-added activities consist of accumulation, creation or dissemination of knowledge for the purpose of developing a customized service [Bettencourt et al., 2002]. They usually show superior innovation competences and develop new routines to improve products and processes, are able to create innovations in products and processes, hence, obtaining higher levels of firm 
performance. Being knowledge-intensive, the contemporary global IT industry deals with high technology, and relies on some considerable investments in research and development and innovation.

Despite the positive forecasts for rapid growth of the Russian IT market in 20152020 , it has slowed down due to recent political and regulatory pressures (the conflict in Ukraine and subsequent economic sanctions). The weak diversification (high dependence on the energy sector and energy price fluctuations) is also a serious constraint on the development of the national economy and the IT sector in particular.

Meanwhile, the Russian government is developing a favorable environment for IT companies, for instance, by launching Science \& Technology Parks (8 out of 30 across the country are IT parks). On average, the IT industry generates $\$ 10$ bn per year. However, despite the large volumes of export and the overall profitability of the IT sector, its absolute contribution to the total Russian GDP had only reached $1.5 \%$ by the end of 2014 [Titorenko, 1999]. At the same time, in developed economies the IT industry has a higher level of contribution to the total GDP: in the USA - $5 \%$, in Germany - 3\%, in France $-2.5 \%$.

Despite the problem of growth and development of the IT market in Russia, the local IT labor market remains highly competitive. The key features of the Russian IT labor market are its concentration in the Moscow region, implementation of flexible working practices, gender misbalance (lack of female IT professionals) and a high level of geographical mobility of IT professionals. Many IT companies in Russia are in an ongoing search for employees, since they are launching new projects and products all the time. For example, Kaspersky Lab (information security company) recruits employees with strong competencies in the IT sphere (C, C\#, C++, Python, Javascript). It cooperates with the leading universities of Russia, although many young specialists lack real experience. The national IT labor market has a growing demand for a number of highly qualified IT professionals, and a surplus of specialists with insufficient competencies.

To cope with the problem of insufficient availability of qualified employees many IT companies cooperate with external training centres and universities. For example, Technosev, the largest Russian system integrator, interacts with several training centers in Russia, the USA and Europe: their specialists regularly take part in technical training on vendor solutions - Dell EMC, SAP, Huawei, Juniper. ABBYY, a global leader in content IQ, cooperates with the Moscow Institute of Physics and Technology and other leading specialized Russian universities.

Another solution is to use an internal training provider. For example, Mirapolis, a provider of comprehensive IT solutions, launched its own training centre in 2018 providing training activities to the employees as well as external training services. Digital design has its own IT university providing such programs as an analytics school and a system engineer school. Croc, a large Russian IT service provider and systems integrator, has been engaged in career guidance for schoolchildren and students in IT for ten years. The company helps them to build a professional track from school through the right university to a particular industry. One of the well-known projects by Croc on developing basic IT competencies in secondary school is called "School of IT solutions". Within several months the participants work out IT projects under the guidance of experts. This project is also supported by Cisco, Yandex, Kaspersky Lab.

The IT sector in India emerged in 1967 at Mumbai and achieved the significant growth within 1970-2000. It witnessed the start of software exports, the setting up of software technology parks along with the evolution of offshore companies and the entry of foreign multinational corporations [Cherian, Kamalanabhan, 2019].

India's IT companies are mainly concentrated in 7 cities: Bangalore (Karnataka), 
Mumbai (Maharashtra), Hyderabad (Andhra Pradesh), Pune (Maharashtra), Kolkata (West Bengal), Gurgaon (Harijana) and Noida (Uttar Pradesh).

In general, the situation looks contradictory. India is a country of IT operations, due to extremely low labour costs, service outsourcing is rapidly developing here, which is increasingly tightening the requirements for employees. A study conducted by National Institute of Mental Health and Neuroscience (NIMHANS) $^{1}$ in Bangalore, provided the following data: more than $36 \%$ of technicians have severe mental disorders. 1 out of 20 IT professionals seriously think about suicide, $27.6 \%$ of IT workers are addicted to various drugs. Suicide, health problems, family conflicts due to the strongest pressure at work and long, unregulated working days seriously distort personal relationships. 14-18 hours of daily work in an office is considered the perfect norm in the IT industry. Indian IT professionals are experiencing problems related to stress, sexual and racial abuse, and dissatisfaction at work [Budhwar, Luthar, Bhatnagar, 2006]. It all leads to high turnover and attrition rates, misbalance between demand and supply of IT specialists, supplementary recruiting and training expenses. At the same time, Indian IT companies expect from the applicants a high level of technical expertise as well as professional flexibility, learning agility and customer orientation. Meanwhile, the talented professionals require from the employers not only an attractive salary and benefits, but also continuous learning, career and professional growth opportunities, challenging tasks [Cherian, Kamalanabhan, 2019]. Overall, although there is a large pool of local labor for the Indian IT industry, the competencies of most of them are still lacking by international standards [Thite, Budhwar, Wilkinson, 2014].

In addition, the country's IT sector is focused on fulfilling international orders in prejudice of the national IT industry develop-

${ }^{1}$ URL: http://nimhans.ac.in/ (accessed: 01.06. 2020). ment. Therefore, the country's prospects in IT are closely related to overcoming poverty, reducing administrative barriers and changing investors' focus from exploiting their human resources (both as IT workers and consumers) to the development of the environment and consumer demand.

Summing up the analytical review above, it can be concluded that both Russian and Indian labor markets are mainly concentrated in large cities, and the problem of deficiency of highly qualified IT professionals presses the employers to implement new approaches to managing their human resources.

\subsection{HRM in Russian and Indian IT companies}

Researchers who have studied the HRM system in Russian companies believe that current HRM practices are strongly affected by the Soviet heritage and modern western HRM models [Fey, Denison, 2003; Zavyalova, Kosheleva, Ardichvili, 2011; Morley, Minbaeva, Michailova, 2012]. The HRM practices in Russian firms are full of contradictions: low/high wage differentiation, large/limited number of benefits, weak/strong relationship between individual performance and remuneration, longterm systematic/short-term spontaneous training and development [Andreeva et al., 2014]. The studies also suggest that the existing HRM system in Russian companies still has a short-term administrative focus [Ardichvili, Dirani, 2005]. The Russian HRM system is described by such attributes as an authoritarian leadership, concentration of decision-making at the top level, lack of employees' rights protection, poor formalization of employees' performance assessment, small share of officially guaranteed payment, unwillingness to invest in personnel.

There are a number of studies on HRM practices in Russian MNCs and national industrial enterprises; however, very few of them survey IT firms. At the same time, HR 
portals and websites publish analytics and interviews with HR practitioners from IT companies.

The largest IT company in Russia is "Rostec State Corporation" established in 2007 to produce, develop and export high-tech industrial civilian and military products. It consists of more than 700 organizations, of which currently 14 holding companies are formed. O. Malashkina, head of the HR direction in the Shvabe holding of the Rostec State Corpo-ration, presented the relevant HRM tools: strategic and tactical workforce planning in accordance with the business strategy, development of competency frameworks, research in industrial wage and benefits, analysis of the efficiency of the human resources allocation in the organizations of the holding.

Practitioners state that recruitment and selection of IT specialists are not regular tasks for HR managers since the traditional methods are not always used here. A. Palekhova, head of the branch at the iChar recruiting agency, points out that the most effective ways for searching IT candidates are social networks (Telegram channels related to IT areas, LinkedIn, VKontakte, Facebook, Github a network for IT professionals). Job sites (hh. $\mathrm{ru}$, job.ru) and professional associations, IT conferences, forums and groups are less effective as they produce a low response from candidates.

Problems of HR development in an IT company, according to the opinion of experts from the recruitment agency Luxoft-personnel, include a decrease in the amount of training and development investments; low level of employees' motivation and performance; lack of professional competencies. Furthermore, unclear reward processes lead to high staff turnover. The salary of IT specialists who have been "cultivated" in the organization since its launch is not attractive since it does not differ much from that of others. Some authors believe that in IT companies the reward system should be based on intellectual investments and individual contribution of each IT professional; besides, a transparent system of bonuses for the project is to be implemented [Krylov, Kozlyaeva, Krylova, 2016].

One of the main tasks for an IT company is to retain highly qualified IT professionals. Many Russian IT firms provide continuous training and development programs for the employees and implement internships for students (Yandex, Mail.ru Group, Kaspersky Lab). Training and development programs are not only aimed to promote employees, but also to increase their loyalty to the company

The previous research [Zavyalova, Kucherov, Tsybova, 2018] revealed that successful Russian IT companies delivered high-quality products and services to customers. Their high-quality and high-productivity orientation was based on a strategic approach to managing their human resources through investing in training and developing professionals. This allows us to assume that these companies have a hybrid HRM system, consisting of both high-performance and high-involvement HRM practices.

Practitioners are unanimous in their opinion about the significant differences in the working behavior of Russian and Indian IT workers and related management practices. According to E. Griva, there is no integration of Indians into the corporate culture of any company. Indians fulfill established requirements while remaining process-oriented, preaching contemplative approach to life, clearly observing the hierarchy and distribution of official duties, good-natured, never saying "no" and not going to conflict, prone to harmony more than to self-expression and development motivation [Griva, 2014]. These qualities largely determine the difficulty in building employee selection, reward system, job hierarchy, reporting. According to the E. Griva, in India it is not customary to use the indicator of labor productivity per employee, since often there is no data on the exact number of personnel.

A review of the literature published on HR-related research in India (e.g., [Budhwar, Varma, 2010]) reveals that scholars have been pursuing research on a variety of India-related 
HR issues, such as evolution of the Indian personnel function [Sparrow, Budhwar, 1997], the role of unions and industrial relations in the new economic environment [Ratnam, 1998], factors determining HRM and organizational commitment [Sparrow, Budhwar, 1997], HRM in multinationals operating in India [Björkman, Budhwar, 2007], national culture and its impact on HRM [Sparrow, Budhwar, 1997], talent management and organizational learning capability [Bhatnagar, 2007], innovative HRM [Som, 2008], employee relations [Budhwar, 2003], comparative HRM in public and private sector organizations [Budhwar, Boyne 2004], HRM in small and medium enterprises (SMEs) [Saini, Budhwar, 2008], emerging patterns of HRM in the business outsourcing sector [Budhwar, Luthar, Bhatnagar, 2006], applicability of western HRM models in India [Budhwar, Khatri, 2001; Björkman, Budhwar, 2007], human resource development area [Sparrow, Budhwar, 1997] and training [Yadapadithaya, 2000] and comparative HRM between India and other countries [Budhwar, Sparrow, 2002].

Furthermore, researchers have also examined various aspects of organizational behavior and organizational dynamics (e.g., [Sahay, Walsham, 1997]), including studying issues related to supervisor-subordinate relationships [Varma, Pichler, Srinivas, 2005; Varma, Srinivas, Stroh, 2005]. With a rapid increase in the number of expatriates moving to India, several scholars have initiated empirical investigations related to their adjustment (e.g., [Varma, Toh, Budhwar, 2006; Thite et al., 2009; Varma et al., 2012]). These examples clearly indicate the kind of HRM issues being explored in relation to the Indian setting. We should point out, however, that the information above is not an exhaustive list of works published on India, and that it is simply meant to be indicative of the increased interest in India-related research.

Based on a qualitative study of 54 Indian managers from different firms, the research by [Cooke, Saini, 2010] highlights the Indian institutional context for strategic HRM. It reveals the extent to which the Western ap- proach to and configuration of high-commitment/performance models of HR practices may differ from those found in Indian firms.

The paper [Jain, Mathew, Bedi, 2012] contained a case study analysis of HRM practices used in Indian IT companies. The case studies of Indian MNCs indicate that innovations in HRM practices are prevalent and are being adopted by high-tech firms operating in India. An analysis of three Indian IT companies shows variation of different types of such practices. For instance, Wipro emphasized performance appraisal, training and development (using collaborative learning), team work, and work-life balance, whereas MindTree focused on a supportive culture using employee training and development; compensation and benefits analysis and pay band design; use of recruitment strategies such as internal referrals, and a variety of performance measurement and appraisal techniques. In the case of Sasken, an emphasis on creativity is obvious. They take care to enhance employee empowerment, freedom, remove fear of failure, encourage performance-based growth and incentives, flexi-time, work-life balance and open communication.

Another research based on case studies among 25 Indian local software companies revealed a number of HRM challenges, including a shortage of software professionals who have sufficient knowledge and competencies, low-skilled nature of the work, high employee turnover, lack of work-life balance [Agrawal, Khatri, Srinivasan, 2012]. These problems were attributed to the poorly developed HR systems and processes. The cases confirmed the lack of matured recruitment processes and effective job rotation, career and succession planning, coaching and mentoring, development of leadership and management skills.

Researchers have noted that national HR practices are determined by both "culturefree" (age, size, and nature of organization) and "culture-bound" (national culture and institutions) factors [Baruch, Budhwar, 2006]. Investigation into the influence of both culture-free and culture-bound variables in a 
cross-national context has been crucial in the comparison of a developed nation and an emerging nation.

An overview of the innovative HRM practices in Indian companies [Jain et al., 2012] allows us to conclude that most of the innovative practices are standard HRM practices in the specific areas, such as performance appraisal, training and development, compensations.

Overall, organizations adopt HRM practices for a variety of reasons. The antecedents of innovative HRM practices include national environment (extent of unionization and sector characteristics, technological sophistication), organizational restructuring and ownership structure, legitimizing driver (use of international consultants), organizational culture and the role of HR department. Because of the shortage of talent in the industry, the leading Indian IT companies started to implement a strategic approach to managing its human resources to source, retain and develop their talent [Mulla, Premarajan, 2008]. This approach is based on the following set of practices: employee involvement, talent management, employee development, performance management, efficiency of HR processes and measuring HR.

Summing up the analytical review above, it can be concluded that both Russian and Indian IT companies started to implement the new strategic approach in managing human resources in order to recruit and retain the needed talent. In particular, special attention is given to e-recruitment practices and use of both external and internal providers to enhance the quality of the human capital. Meanwhile, very little is known about the organizational outcomes from such initiatives.

\section{RESEARCH METHODOLOGY}

We chose an exploratory research design because the problem of HPWSs in the emerging market context is sparse. Moreover, there is still a lack of relevant cross-cultural studies in this context, mainly available for developed countries [Gilman, Raby, 2013]. Exploratory research is conducted into an issue when there are limited or no earlier studies to which academic scholars can refer for information about the issue or problem [Saunders, Lewis, Thornhill, 2007]. The hypotheses for such research are absent at all or are vague. Because of lack of empirical evidence in the chosen context our research is limited by the set of the research questions, and no hypotheses are stated.

The present study employed the quantitative methodology to answer the research questions.

Research question 1. What types of HPWSs are used by Russian and Indian IT companies?

Research question 2. What is the relationship between HPWSs and performance of Russian and Indian IT companies?

We used a cross-sectional survey design. The questionnaire for the survey was prepared on the basis of the well-known European quality standard "Investors in people".

We found that IiP, developed and applied in the UK as a framework for the assessment of HRM systems in organisations, met our requirements. The standard was developed by the Confederation of British Industry and the British Trade Union Congress for the purpose of assisting organisations in developing more effective personnel management systems. Later on, in 1991, the organisation IiP, which deals with the development and dissemination of this standard around the world, was set up.

The IiP assessment system was designed to improve business performance through system strategies of organisational management based on involving employees in decisionmaking and goal-setting. The standard requires the creation of an organisational business strategy through a new policy and a new HRM philosophy. A highly important result of introducing the philosophy of employee involvement in goal-setting is that people stop being afraid of changes, become their initiators and strive for further business development and prosperity. There are 39 requirements which a company must meet in order to obtain the IiP certificate. This mod- 
el is mainly focused on people, to be more exact, on their development in accordance with the business strategy of the company. The application of the IiP standard has been a subject of numerous research studies, which demonstrated a positive impact of the implementation of the standard and related development strategies on organisational performance and employees' well-being [Bell, Taylor, Thorpe, 2001].

The previous research on application of the IiP is based on the idea that improved HR practices would create a more positive organizational social climate and enhance the skills and flexibility of employees [de Waal, 2016] which, in turn, could improve organizational performance. In our case, we expect the same impact of the HPWPs on performance. The positive impact of HPWPs on organizational performance is the key attribute for HPWS.

The IiP survey instrument includes approximately 100 questions, and covers sections on selection, compensation and rewards policy, training and development policy, people management, employee behaviour flexibility, social climate (including trust, cooperation, and commitment), and business strategy.

Based on the questions found in the IiP instrument for considering and assessing employment practices in Russian IT companies during a crisis, we created an instrument containing 39 questions that cover the following topics: goal-setting; decision-making; management; performance appraisal; HRM practices; and organizational values.

This questionnaire was successfully tested in the previous studies [Kucherov, Zavyalova, 2012; Zavyalova, Kucherov, Tsybova, 2018]. The text of selected questions from the IiP instrument was translated into Russian and then back-translated into English to assess the quality of translation. Questions were based on ordinal and nominal scales.

\subsection{Sample and data collection}

Participants were selected on the basis of non-probability sampling. The initial con- venience sample consisted of 58 Russian and 74 Indian IT companies. All these companies are software developers; hence their competitiveness is completely dependent on the intellectual capital of the employees. There was one respondent from each company; and the chosen person was able to answer the questions related to HRM and GM practices, business processes and communication management in the organization.

Table 1 shows the final sample distribution of Russian and Indian IT companies, based on the number of full-time employees, respondent position and market (markets) where the company operates.

\subsection{Measures}

HRM practices. For our current research goal, namely, to investigate the features of approaches to HRM in Russian and Indian IT-companies, we analyzed responses from 4 sections of the questionnaire: recruitment, selection, training and development, assessment, promotion and compensation. All the items were the closed format questions. The section included factual items (e.g., "What HRM practices are used in your company?") and attitudinal items (e.g., "How satisfied are you by the current HRM practices in your company?").

Genaral management (GM) practices. Additional variables related to general management such as goal-setting, decision-making process and oraganizational values were analyzed. These are closely related to personnel management, the degree of employees' freedom in the organization and can be seen as part of HPWPs. All the items were the closed format questions. The section included factual items (e.g., "In what way are you personally involved in improving and upgrading the performance of your organization?").

Performance measures. To measure the performance indicators, we created a separate item included in the demographics section ("Please note, how the following indicators of your company's activities have changed 
Sample description

\begin{tabular}{l|l|c|c}
\hline \multicolumn{1}{c|}{ Variable } & \multicolumn{1}{c|}{ Category } & Russia, $\%$ & India, $\%$ \\
\hline Number of full-time & $200-500$ & 70.69 & 40.54 \\
employees & $501-750$ & 6.90 & 31.08 \\
& $751-1000$ & 8.60 & 0.00 \\
& $1001-1250$ & 3.50 & 0.00 \\
& $1251-1500$ & 1.70 & 13.51 \\
& $1501-2000$ & 3.50 & 9.46 \\
& More than 2000 & 5.20 & 5.41 \\
\hline Respondent position & CEO & 5.26 & 25.68 \\
& Development director & 7.02 & 8.11 \\
& HR Director & 57.89 & 4.05 \\
& HR Manager & 10.53 & 0.00 \\
& Head of Department & 7.02 & 20.27 \\
& Other Managers & 5.26 & 4.05 \\
& Head of Customer Services & 1.75 & 0.00 \\
& IT Professional & 5.26 & 35.14 \\
\hline Market (markets) where & B2C market & 3.45 & 17.57 \\
the company operates & B2B market & 60.34 & 43.24 \\
& B2C market and B2B market & 36.21 & 39.19 \\
\hline
\end{tabular}

over the last year"). The following performance indicators were included: net profit and sales volume. These measures represent the overall firm performance and were used in a number of previous studies on strategic HRM as relevant dependent variables (e.g., [Delery, Gupta, 2016; Harris, Ogbonna, 2001; Green et al., 2006]). It should be noted that this measurement was subjective as with these indicators the respondents could specify changes ("increased" or "decreased" for $0-24 \%, 25-49 \%, 50-74 \%$, $75-100 \%$ or "remained fixed") over the last year.

\section{ANALYSIS AND RESULTS}

\subsection{Descriptive analysis}

In order to answer the first research question (to find significant differences in HRM practices implemented in Russian and Indian IT companies), a frequency analysis was conducted together with a two-sample proportion test ( $Z$-statistics) to find significant differences in HRM and GM practices in the selected countries. The main results are presented in Table 2 (only variables where significant differences were found are shown in the table).

Table 2 presents only 17 HRM and GM practices (out of 101 varied HRM practices with significant differences in two samples) that were included in the final regression models.

The results indicate that unlike Indian IT firms, Russian IT companies perceive the value of HRM programs devoted to training and development. The empirical findings show that in most cases training needs of employees are satisfied. As seen, Russian IT companies provide the financial support for those employees who need external training. At the same time, they expand the internal training programs. Thus, despite the general trend for Russian companies to decrease the employee surplus and number of training programs, the IT 
Table 2

HRM and GM practices in Russian and Indian IT companies

\begin{tabular}{|c|c|c|c|}
\hline HRM and GM practices & Russia, \% & India, $\%$ & $Z$ \\
\hline \multicolumn{4}{|l|}{ Section 1. Goals of organization } \\
\hline $\begin{array}{l}\text { Employees are personally involved in improving and upgrading the } \\
\text { organizational performance by making individual contacts with the } \\
\text { supervisor (the corresponding variable code }- \text { gl8_1) }\end{array}$ & 85.19 & 14.86 & $8.75 * *$ \\
\hline $\begin{array}{l}\text { Organization rarely encounters a situation when the orders and } \\
\text { instructions of one manager contradict the orders and instructions of } \\
\text { another one (gl11) }\end{array}$ & 3.8 & 41.67 & $-5.62 * *$ \\
\hline
\end{tabular}

\section{Section 2. Decision-making}

Employees receive information letters about the upcoming decisions (dm14_2)

\section{Section 3. Employee training}

Professional practical skills are needed for employees to perform their work in the organization $\left(\operatorname{tr} 15 \_4\right)$

Such a goal of employee training and development, as improvement of goods and service quality, is important or highly important for the organization (tr18_4)

Such a goal of employee training and development, as improvement of the organization reliability as a whole, is important or highly important for the organization (tr18_5)

Employee training and development affects or mostly affects improvement of goods and service quality (tr19_4)

38.27

12.20

$2.98 * *$

Section 4. Performance evaluation

Managers in the organization usually inform employees about their assessment of the employees' work performance by reviewing on the corporate website (ast31_5)

Managers in the organization periodically (after the execution of a part of tasks) or regularly (after each assignment) inform employees about their assessment of the employees' work performance (ast32)

Organization recognizes and evaluates individual contributions of its employees by promotion (ast34_1)

Section 5. Recruitment and selection

\begin{tabular}{|l|l|l}
\hline 33.77 & 68.92 & $-4.32 * *$ \\
\hline 95.95 & 67.56 & $4.47 * *$ \\
\hline 86.48 & 63.52 & $3.23 * *$ \\
\hline 91.03 & 71.62 & $3.08 * *$ \\
\hline
\end{tabular}

\begin{tabular}{l|l|l|l}
\hline 4.94 & 25.68 & $-3.63 \% *$ \\
& & & \\
\hline 60.13 & 91.78 & $-3.50 \% *$ \\
\hline
\end{tabular}

\begin{tabular}{|c|c|c|c|}
\hline Planned promotion is used as a method to recruit applicants (pm36_2) & 50.00 & 0.00 & $7.07 * *$ \\
\hline $\begin{array}{l}\text { The search for applicants from the organization's database of resumes } \\
\text { is used as a method to recruit applicants (pm36_7) }\end{array}$ & 53.75 & 2.70 & $6.96 * \%$ \\
\hline Professional tests are used as a method to select applicants (pm37_2) & 72.84 & 60.27 & $1.65 *$ \\
\hline Psychological tests are used as a method to select applicants (pm37_3) & 23.46 & 56.16 & $-4.16 * *$ \\
\hline $\begin{array}{l}\text { Unstructured interviews with applicants are used as a method to select } \\
\text { applicants (pm37_4) }\end{array}$ & 62.96 & 23.29 & $4.95 * *$ \\
\hline $\begin{array}{l}\text { Structured interviews with applicants are used as a method to select } \\
\text { applicants (pm37_5) }\end{array}$ & 74.07 & 60.27 & $1.83 *$ \\
\hline
\end{tabular}


Table 2 (end)

\begin{tabular}{l|c|c|c}
\hline \multicolumn{1}{c|}{ HRM and GM practices } & Russia, \% & India, \% & $Z$ \\
\hline \multicolumn{3}{c}{ Section 6. The values of the organization } & \\
\hline $\begin{array}{l}\text { Organization mostly or fully shares such a value as respect for } \\
\text { employees (v139_9) }\end{array}$ & 89.88 & 98.65 & $-2.31 * *$ \\
\hline
\end{tabular}

Note: $* * *$ indicate significance at the 10 and $5 \%$ level, respectively.

sector continues to invest in employee training programmes to develop intellectual capital and support organizational renewal and transformation.

The results of HRM practices also show that Russian companies prefer to use planned promotion as a method of recruiting, while the surveyed Indian IT firms do not consider it at all. At the same time, Indian companies use promotion as manifestation of recognition of the individual's contribution to the organization. Moreover, the selection process differs as well. Russian IT companies rely on professional tests, structured and unstructured interviews, whereas Indian firms prefer to use psychological tests.

\subsection{Regression analysis}

In Table 3, the results of a regression analysis are presented. During the regression analysis, the relationship between HRM and GM practices and net profit (Model 1) and sales volumes (Model 2) in Russian and Indian IT companies were studied. Several trials of multiple regression models were conducted, and 17 practices out of 101 HRM practices that are significantly different in the surveyed countries are included in the final models. The aim of the multiple regression in this case is to find the predictors for companies' outcomes. We use a standard procedure of wise exclusion of non-significant variables according to the rules of statistical data analysis (established p-value is 0.05) (for more details see [Nasledov, 2008; Hastie, Tibshirani, Friedman, 2009]). Both final models are sig- nificant as well as HRM and GM practices (see Table 3).

Model 1 shows that in Russian IT companies more HRM practices are related to net profit than in Indian ones. Those practices mostly highlight selection and recruitment, training and development, and performance assessment methods used. At the same time, Indian companies relate HRM practices of goal-setting and decision-making to the net profit of the organization.

Model 2 demonstrates that in Russian companies HRM practices related to selection and recruitment and performance assessment affect the sales volume, while in Indian companies it is influenced by training and development practices.

It should be noted that some of the HRM practices have a negative effect. For Russian companies, the use of a psychological test as a selection procedure negatively affects both the net profit and the sales volume; promotion as an appraisal method and contradictions in orders and instructions have a negative impact on the net profit, and internal recruiting (by promotion) negatively influences the sales volume. For Indian IT firms, the importance of such a goal of the employee training and development as improvement of goods quality has a negative effect on the sales volume.

\section{DISCUSSION AND CONCLUSION}

In the research reported here, we investigated the HPWPs used in successful Russian and Indian IT companies. Our approach was based on the bundling perspective: we expected that the consistent set of HRM prac- 
Results of regression analysis

\begin{tabular}{|c|c|c|c|c|c|c|c|}
\hline \multirow{2}{*}{ HRM practice } & \multirow{2}{*}{$\begin{array}{l}\text { Var } \\
\text { code }\end{array}$} & \multirow{2}{*}{ Mean } & \multirow{2}{*}{$\begin{array}{l}\text { Standard } \\
\text { deviation }\end{array}$} & \multicolumn{2}{|c|}{$\begin{array}{l}\text { Model 1 } \\
\text { Net profit }\end{array}$} & \multicolumn{2}{|c|}{$\begin{array}{c}\text { Model } 2 \\
\text { Sales volume }\end{array}$} \\
\hline & & & & Russia & India & Russia & India \\
\hline $\begin{array}{l}\text { Employees are personally involved in } \\
\text { improving and upgrading the } \\
\text { organizational performance by making } \\
\text { individual contacts with the supervisor }\end{array}$ & gl8_1 & 0.516 & 0.501 & - & $\begin{array}{c}3.89 \\
(0.000)\end{array}$ & - & - \\
\hline $\begin{array}{l}\text { Organization rarely encounters a situation } \\
\text { when the orders and instructions of one } \\
\text { manager contradict the orders and } \\
\text { instructions of another one }\end{array}$ & gl11 & 2.417 & 1.163 & $\begin{array}{c}-2.13 \\
(0.043)\end{array}$ & - & - & - \\
\hline $\begin{array}{l}\text { Employees receive information letters } \\
\text { about the upcoming decisions }\end{array}$ & dm14_2 & 0.295 & 0.458 & - & $\begin{array}{c}1.76 \\
(0.087)\end{array}$ & $\begin{array}{c}4.67 \\
(0.000)\end{array}$ & - \\
\hline $\begin{array}{l}\text { Professional practical skills are needed } \\
\text { for employees to perform their work in } \\
\text { the organization }\end{array}$ & $\operatorname{tr} 15 \_4$ & 0.510 & 0.502 & - & - & - & $\begin{array}{c}1.95 \\
(0.055)\end{array}$ \\
\hline $\begin{array}{l}\text { Such a goal of employee training and } \\
\text { development, as improvement of the } \\
\text { goods and service quality, is important } \\
\text { or highly important for the organization }\end{array}$ & $\operatorname{tr} 18 \_4$ & 3.331 & 0.868 & - & - & - & $\begin{array}{c}-2.41 \\
(0.019)\end{array}$ \\
\hline $\begin{array}{l}\text { Such a goal of employee training and } \\
\text { development, as improvement of the } \\
\text { organization reliability as a whole, is } \\
\text { important or highly important for the } \\
\text { organization }\end{array}$ & $\operatorname{tr} 18 \_5$ & 3.088 & 1.036 & $\begin{array}{c}3.21 \\
(0.004)\end{array}$ & - & - & - \\
\hline $\begin{array}{l}\text { Employee training and development } \\
\text { affects or mostly affects improvement } \\
\text { of goods and service quality }\end{array}$ & $\operatorname{tr} 19 \_4$ & 3.145 & 0.825 & - & - & - & $\begin{array}{c}2,62 \\
(0.011)\end{array}$ \\
\hline $\begin{array}{l}\text { Managers in the organization usually } \\
\text { inform employees about their } \\
\text { assessment of the employees' work } \\
\text { performance by reviewing on the } \\
\text { corporate website }\end{array}$ & ast31_5 & 0.148 & 0.357 & $\begin{array}{c}2.08 \\
(0.048)\end{array}$ & - & - & - \\
\hline $\begin{array}{l}\text { Managers in the organization periodically } \\
\text { (after the execution of a part of tasks) or } \\
\text { regularly (after each assignment) inform } \\
\text { employees about their assessment of the } \\
\text { employees' work performance }\end{array}$ & ast32 & 2.091 & 0.699 & - & - & $\begin{array}{c}4.21 \\
(0.000)\end{array}$ & - \\
\hline $\begin{array}{l}\text { Organization recognizes and evaluates } \\
\text { individual contributions of its } \\
\text { employees by promotion }\end{array}$ & ast34_1 & 0.673 & 0.471 & $\begin{array}{c}-5.34 \\
(0.000)\end{array}$ & - & - & - \\
\hline $\begin{array}{l}\text { Planned promotion is used as a method } \\
\text { to recruit applicants }\end{array}$ & pm36_2 & 0.260 & 0.440 & - & - & $\begin{array}{c}-4.76 \\
(0.000)\end{array}$ & \\
\hline $\begin{array}{l}\text { The search for applicants from the } \\
\text { organization's database of resumes is } \\
\text { used as a method to recruit applicants }\end{array}$ & pm36_7 & 0.292 & 0.456 & - & - & - & $\begin{array}{c}2.82 \\
(0.006)\end{array}$ \\
\hline
\end{tabular}


Table 3 (end)

\begin{tabular}{|c|c|c|c|c|c|c|c|}
\hline \multirow{2}{*}{ HRM practice } & \multirow{2}{*}{$\begin{array}{l}\text { Var } \\
\text { code }\end{array}$} & \multirow{2}{*}{ Mean } & \multirow{2}{*}{$\begin{array}{l}\text { Standard } \\
\text { deviation }\end{array}$} & \multicolumn{2}{|c|}{$\begin{array}{c}\text { Model } 1 \\
\text { Net profit }\end{array}$} & \multicolumn{2}{|c|}{$\begin{array}{c}\text { Model } 2 \\
\text { Sales volume }\end{array}$} \\
\hline & & & & Russia & India & Russia & India \\
\hline $\begin{array}{l}\text { Professional tests are used as a method } \\
\text { to select applicants }\end{array}$ & pm37_2 & 0.669 & 0.472 & $\begin{array}{c}2.50 \\
(0.020)\end{array}$ & - & - & - \\
\hline $\begin{array}{l}\text { Psychological tests are used as a } \\
\text { method to select applicants }\end{array}$ & pm37_3 & 0.390 & 0.489 & $\begin{array}{l}-2.32 \\
(0.029)\end{array}$ & - & \begin{tabular}{|l|}
-3.28 \\
$(0.003)$
\end{tabular} & - \\
\hline $\begin{array}{l}\text { Unstructured interviews with } \\
\text { applicants are used as a method to } \\
\text { select applicants }\end{array}$ & pm37_4 & 0.442 & 0.498 & $\begin{array}{c}2.75 \\
(0.011)\end{array}$ & - & $\begin{array}{c}4.15 \\
(0.000)\end{array}$ & - \\
\hline $\begin{array}{l}\text { Structured interviews with applicants } \\
\text { are used as a method to select } \\
\text { applicants }\end{array}$ & pm37_5 & 0.675 & 0.470 & $\begin{array}{c}2.11 \\
(0.045)\end{array}$ & - & - & - \\
\hline $\begin{array}{l}\text { Organization mostly or fully shares } \\
\text { such a value as respect for employees }\end{array}$ & vl39_9 & 3.444 & 0.606 & - & - & $\begin{array}{c}3.94 \\
(0.000) \\
\end{array}$ & - \\
\hline \multicolumn{4}{|l|}{ Intercept } & $\begin{array}{c}1,67 \\
(0,108)\end{array}$ & $\begin{array}{c}29.45 \\
(0.000)\end{array}$ & $\begin{array}{c}0.34 \\
(0.733)\end{array}$ & $\begin{array}{c}6.64 \\
(0.000)\end{array}$ \\
\hline \multicolumn{4}{|l|}{$\overline{R^{2}}$} & 0.7202 & 0.3489 & 0.7273 & 0.2537 \\
\hline \multicolumn{4}{|l|}{$N$} & 34 & 41 & 38 & 74 \\
\hline \multicolumn{4}{|l|}{$F(8,25)$} & 8.04 & 10.18 & 13.78 & 5.86 \\
\hline \multicolumn{4}{|l|}{ Prob $>F$} & 0.0000 & 0.0003 & 0.0000 & 0.0004 \\
\hline
\end{tabular}

N o t e: "-“ indicates that the variable was omitted in the final regression model.

tices would improve the corporate performance. Meanwhile, HRM practices are essentially embedded in legal and cultural contexts [Kim, Wright, 2010]. Therefore, the national institutional environment impacted the differences between bundles in Russian and Indian IT-companies, hence the construction of two unique HPWSs. The context itself becomes an important element of the comprehensive HRM system [Bondarouk, Brewster, 2016]. As seen from the "Harvard" model [Beer et al., 1985], the contextual factors include different external elements, including workforce characteristics, labour market, laws and societal values, business conditions. HRM becomes the most localized of management practices, which are affected by different cultures and different institutions [Rosenzweig, Nohria, 1994].

Using "Investors in people" as a quality standard for developed economies, we try to apply it to the HRM landscape of the IT sec- tor for developing economies of Russia and India. We were concerned with how it would match the current HPWSs of Russian and Indian IT companies, and what the relationship was between HPWSs and performance of Russian and Indian IT companies.

The current study makes the following contributions to the extant research in the field of HPWSs. Firstly, we identified that there are differences in HRM practices used in Russian and Indian IT companies. Russian IT companies actively use decentralized participative decisions, which are frequently considered an important HPWP [Posthuma et al., 2013]. Employees are delegated with authority and are provided with information required for decision-making. Internal recruiting is often used as a tool to fill the vacancy and also as an instrument for career management. Multiple selection tools (screening, testing, interviews) are implemented to choose the most suitable professional. The 
particular measures (e.g., quality of goods and services) are used to evaluate training outcomes. The most popular forms of training are mentoring, funded training opportunities and in-house training of employees. Regular feedback on performance is given to employees through appraisal interviews. The current findings also correspond with the previous research [Zavyalova, Kucherov, Tsybova, 2018] that in the IT industry, companies with high-quality and high-productivity orientation need people with innovative thinking and creative mind. To develop these competencies, extensive and continuous training initiatives are implemented. Training extensiveness and decentralized participative decisions show that the Russian IT companies from the sampling have a high-involvement HRM system.

Indian IT companies, in contrast, do not use internal recruiting. Instead, they are ready to recruit applicants from the external labor market. To evaluate their competencies psychological tests and interviews are used. Respect for employees is the core corporate value. There is no mismatch in communication flows to employees from managers. The individual contribution is highly appreciated and rewarded, and feedback is given from supervisors to subordinates. These attributes show that the Indian IT companies from the sampling have a high-commitment HRM system.

Secondly, we found that both Russian and Indian HPWSs related to performance. At the same time, there are differences in the set of HPWPs which related to performance between two institutional contexts. In Indian IT companies we found the relationship between goal-setting, decision-making, training practices and corporate performance. Such relationship between a high-commitment HRM system and corporate outcomes could be explained through social exchange theory: when employees perceive organization to be helping or caring toward them, they tend to return organization's favors and reciprocate the organization through positive attitudes and behaviors [Yousaf, Sanders, Yustantio, 2018]. Meanwhile, Russian IT companies use an extensive set of recruitment, selection, training and development, performance appraisal practices that impact the employee behavior and corporate outcomes. Such HPWS is aimed to check and improve employee competencies or specific human capital: employees' competencies acquired, selected, trained and developed from high-performance HR practices are the proximal antecedent to firm performance [Van Esch, Wei, Chiang, 2018].

Thirdly, we compared the well-known European quality standard "Investors in people" applied in developed economies with the existing HPWSs from two developing economies, Russia and India. IiP is a quality standard by which organisations measure themselves in relation to their human resources practices. The standard follows the idea that improved HR practices create a more positive organisational social climate consisting of higher levels of trust, cooperation and people engagement, which, in turn, lead to increased performance [de Waal, 2016]. Russian IT companies are more consistent with the IiP standard in terms of applicable HRM practices.

Our research has several limitations, some of which can be addressed in the future. First, in the data collection procedures we focused on HRM practices used and particular performance indicators, whereas the contextual and institutional factors could also be important in explaining the relationship between practices and performance. In other words, examination of intervening mechanisms through which HPWPs influence firm performance could be the direction for future research. For the case of IT companies such a mediator could be the innovative work behavior, which had already been successfully tested in the previous research on knowledge-intensive firms [Fu et al., 2015]. Secondly, the research design is based on cross-sectional data that limits our inference of causality among HPWPs and firm performance. Future research can adopt a longitudinal design and show some trends and changes in the composition of HPWPs over time and its relationship with performance. 


\section{REFERENCES}

Agrawal N. M., Khatri N., Srinivasan R. 2012. Managing growth: Human resource management challenges facing the Indian software industry. Journal of World Business 47 (2): 159-166.

Andreeva T., Festing M., Minbaeva D., Muratbekova-Touron M. 2014. The Janus faces of IHRM in Russian MNEs. Human Resource Management 53 (6): 967-986.

Ardichvili A., Dirani K. 2005. Human capital practices of Russian enterprises. Human Resource Development International 8 (4): 403-418.

Armstrong M. 2006. Strategic Human Resource Management: A Guide to Action. Kogan Page: London.

Arthur J. B. 1994. Effects of human resource systems on manufacturing performance and turnover. Academy of Management Journal 37 (3): 670-687.

Baruch Y., Budhwar P. S. 2006. A comparative study of career practices for management staff in Britain and India. International Business Review 15 (1): 84-101.

Becker B. E., Huselid M. A. 2006. Strategic human resources management: Where do we go from here? Journal of Management 32 (6): 898-925.

Beer M., Spector B., Lawrence P., Mills D. Q., Walton R. 1985. Human Resource Management: A General Manager's Perspective. Free Press: N.Y.

Bell E., Taylor S., Thorpe R. 2001. Investors in people and the standardization of professional knowledge in personnel management. Management Learning 32 (2): 201-219.

Bettencourt L. A, Ostrom A. L., Brown S. W., Roundtree R. I. 2002. Client co-production in knowledge-intensive business services. California Management Review 44 (4): 100128.

Bhatnagar J. 2007. Predictors of organizational commitment in India: strategic HR roles, organizational learning capability and psychological empowerment. The International Journal of Human Resource Management 18 (10): 1782-1811.
Björkman I., Budhwar P. 2007. When in Rome...? Human resource management and the performance of foreign firms operating in India. Employee Relations 29 (6): 595610.

Bondarouk T., Brewster C. 2016. Conceptualising the future of HRM and technology research. The International Journal of Human Resource Management 27 (21): 2652-2671.

Boxall P. 2012. High-performance work systems: What, why, how and for whom? Asia Pacific Journal of Human Resources 50 (2): 169-186.

Boxall P., Macky K. 2007. High-performance work systems and organizational performance: Bridging theory and practice. Asia Pacific Journal of Human Resources 45 (3): 261-270.

Budhwar P. S. 2003. Employment relations in India. Employee Relations 25 (2): 132-148.

Budhwar P. S., Bhatnagar J. 2008. The Changing Face of People Management in India. Routledge: N.Y.

Budhwar P. S., Boyne G. 2004. Human resource management in the Indian public and private sectors: An empirical comparison. The International Journal of Human Resource Management 15 (2): 346-370.

Budhwar P. S., Khatri N. 2001. HRM in context applicability of HRM models in India. International Journal of Cross Cultural Management 1 (3): 333-356.

Budhwar P. S., Luthar H. K., Bhatnagar J. 2006. The dynamics of HRM systems in Indian BPO firms. Journal of Labor Research 27 (3): 339-360.

Budhwar P. S., Sparrow P. R. 2002. An integrative framework for understanding crossnational human resource management practices. Human Resource Management Review 12 (3): 377-403.

Budhwar P. S., Varma A. 2010. Guest editors' introduction: Emerging patterns of HRM in the new Indian economic environment. $\mathrm{Hu}$ man Resource Management 49 (3): 345-351.

Cherian K., Kamalanabhan T. J. 2019. Organizational and talent attributes of the In- 
dian IT industry. Employee Relations: The International Journal 41 (5): 876-897.

Cooke F. L., Saini D. S. 2010. (How) Does the HR strategy support an innovation-oriented business strategy? An investigation of institutional context and organizational practices in Indian firms. Human Resource Management 49 (3): 377-400.

de Waal A. 2016. Does Investors in People affect organisational performance: A relevant question? Employee Relations 38 (5): 665-681.

Delery J. E. 1998. Issues of fit in strategic human resource management: Implications for research. Human Resource Management Review 8 (3): 289-309.

Delery J. Gupta N. 2016. Human resource management practices and organizational effectiveness: Internal fit matters. Journal of Organizational Effectiveness: People and Performance 3 (2): 139-163.

Dyer L., Reeves T. 1995. Human resource strategies and firm performance: What do we know and where do we need to go? International Journal of Human Resource Management 6 (3): 656-670.

Edwards P., Wright M. 2001. High-involvement work systems and performance outcomes: The strength of variable, contingent and context-bound relationships. International Journal of Human Resource Management 12 (4): 568-585.

Fey C. F, Denison D. R. 2003. Organizational culture and effectiveness: Can American theory be applied in Russia? Organization Science 14: 686-706.

Fu N., Flood P., Wu C., Bosak J., Morris T., O'Regan P. 2015. How do high performance work systems influence organizational innovation in professional service firms? $\mathrm{Em}$ ployee Relations 37 (2): 209-231.

Gilman M., Raby S. 2013. National context as a predictor of high-performance work system effectiveness in small-to-medium-sized enterprises (SMEs): A UK-French comparative analysis. The International Journal of Human Resource Management 24 (2): 372 390.

Green K. W., Wu C., Whitten D., Medlin B. 2006. The impact of strategic human re- source management on firm performance and HR professionals' work attitude and work performance. International Journal of Human Resource Management 17 (4): 559 579.

Griva E. 2014. In India the "boss" is respected... Personnel Management 14. [Electronic resource]. http://www.top-personal.ru/issue.html?3684 (accessed: 1.09.2019). (In Russian)

Guest D. 1997. Human resource management and performance: A review and research agenda. International Journal of Human Resource Management 8 (3): 263-276.

Harris L., Ogbonna E. 2001. Strategic human resource management, market orientation, and organizational performance. Journal of Business Research 51 (2): 157-166.

Hastie T., Tibshirani R., Friedman J. 2009. The Elements of Statistical Learning: Data Mining, Inference, and Prediction. Springer Science \& Business Media: N.Y.

Hauff S., Alewell D., Hansen N. K. 2014. HRM systems between control and commitment: Occurrence, characteristics, and effects on $\mathrm{HR}$ outcomes and firm performance. $\mathrm{Hu}$ man Resource Management Journal 24 (4): 424-441.

Huselid M. 1995. The impact of human resource management practices on turnover, productivity, and corporate financial performance. Academy of Management Journal 38 (3): 635-672.

Jain H., Mathew M., Bedi A. 2012. HRM innovations by Indian and foreign MNCs operating in India: A survey of HR professionals. The International Journal of $\mathrm{Hu}$ man Resource Management 23 (5): 10061018.

Kim S., Wright P. M. 2010. Putting strategic human resource management in context: A contextualized model of high commitment work systems and its implications in China. Management and Organization Review 7 (1): 153-174.

Krylov A. N., Kozlyaeva E. V., Krylova I. Y. 2016. Some human resource management issues in IT companies. Economic Vector 2 (5): $20-22$. 
Kucherov D., Zavyalova E. 2012. HRD practices and talent management in the companies with the employer brand. European Journal of Training and Development 36 (1): 86-104.

Lengnick-Hall M. L, Lengnick-Hall C. A., Andrade L. S., Drake D. 2009. Strategic human resource management: The evolution of the field. Human Resource Management Review 19 (2): 64-85.

Morley M., Minbaeva D., Michailova S. 2012. The transition states of central and eastern Europe and the former Soviet Union. In: C. Brewster, W. Mayrhofer, E. Farndale (eds). Handbook of Research in Comparative Human Resource Management, 550575. Edward Elgar: Cheltenham, UK.

Mulla Z. R., Premarajan R. K. 2008. Strategic human resource management in Indian IT companies: Development and validation of a scale. The Journal of Business Perspective 12 (2): 35-46.

Nasledov A. D. 2008. SPSS 15: Professional Statistical Data Analysis. Publishing House "Piter": St. Petersburg. (In Russian)

Paauwe J., Boselie P. 2005. HRM and performance: What next? Human Resource Management Journal 15 (4): 68-83.

Posthuma R. A., Campion M. C., Masimova M., Campion M. A. 2013. A high performance work practices taxonomy: Integrating the literature and directing future. Journal of Management Research 39 (5): 1184-1220.

Ratnam V. 1998. Economic reforms and labor. Productivity 39 (3): 373-383.

Richard O. C., Johnson N. B. 2001. Understanding the impact of human resource diversity practices on firm performance. Journal of Managerial Issues 13 (2): 177-195.

Richardson R., Thompson M. 1999. The Impact of People Management Practices on Business Performance: A literature Review. Institute of Personnel and Development: London.

Rosenzweig P. M., Nohria N. 1994. Influences on human resource management practices in multinational corporations. Journal of
International Business Studies 25 (2): 229251.

Sahay S., Walsham G. 1997. Social structure and managerial agency in India. Organization Studies 18 (3): 415-444

Saini D. S., Budhwar P. S. 2008. Managing the human resource in Indian SMEs: The role of indigenous realities. Journal of World Business 43 (4): 417-434

Saunders M., Lewis Ph., Thornhill A. 2007. Research Methods for Business Students. Pearson: Harlow.

Som A. 2008. Innovative human resource management and corporate performance in the context of economic liberalization in India. The International Journal of $\mathrm{Hu}^{-}$ man Resource Management 19 (7): 12781297.

Sparrow P. R., Budhwar P. S. 1997. Competition and change: Mapping the Indian HRM recipe against world-wide patterns. Journal of World Business 32 (3): 224-242.

Stavrou E., Brewster C. 2005. The configurational approach to linking strategic human resource management bundles with business performance: Myth or reality? Management Revue 16 (2): 186-201.

Thite M., Srinivasan V., Harvey M., Valk R. 2009. Expatriates of host-country origin: coming home to test the waters. The International Journal of Human Resource Management 20 (2): 269-285.

Thite M., Budhwar P., Wilkinson A. 2014. Global HR roles and factors influencing their development: evidence from emerging Indian IT services multinationals. Human Resource Management 53 (6): 921-946.

Titorenko G. A. 1999. Automated Information Technologies in Economics. Unity: Moscow.

Van Esch E., Wei L. Q., Chiang F. 2018. Highperformance human resource practices and firm performance: The mediating role of employees' competencies and the moderating role of climate for creativity. The International Journal of Human Resource Management 29 (10): 1683-1708.

Varma A., Grodzicki J. P., Pichler S., Kupferer S., Ramaswami A. 2012. Expatriate categorisation and evaluation: An empirical 
investigation in Poland and India. European Journal of International Management 6 (1): 63-82.

Varma A., Pichler S., Srinivas E. S. 2005. The role of interpersonal affect in performance appraisal: evidence from two samples-the US and India. The International Journal of Human Resource Management 16 (11): 2029-2044.

Varma A., Srinivas E. S., Stroh L. K. 2005. A comparative study of the impact of leader-member exchange in US and Indian samples. Cross Cultural Management: An International Journal 12 (1): 84-95.

Varma A., Toh S. M., Budhwar P. 2006. A new perspective on the female expatriate experience: The role of host country national categorization. Journal of World Business 41 (2): 112-120.

Walton R. 1985. From Control to Commitment in the Workplace. Harvard Business Review March-April: 77-84.

Wood S. 1996. High commitment management and unionization in the UK. International
Journal of Human Resource Management 7 (1): 41-58.

Yadapadithaya P. S. 2000. International briefing 5: Training and development in India. International Journal of Training and Development 4 (1): 79-89.

Yousaf A., Sanders K., Yustantio J. 2018. High commitment HRM and organizational and occupational turnover intentions: the role of organizational and occupational commitment. International Journal of Human Resource Management 29 (10): 1661-1682.

Zavyalova E., Kosheleva S., Ardichvili A. 2011. Human resource management and development practices in indigenous Russian companies and foreign MNCs: A comparative analysis. International Journal of $\mathrm{Hu}$ man Resources Development \& Management 11 (2-4): 179-193.

Zavyalova E., Kucherov D., Tsybova V. 2018. Approaches to HRD in Russian IT-companies in the period of economic crisis. $\mathrm{Hu}$ man Resource Development International 21 (4): 319-339.

Initial Submission: December 21, 2019 Final Version Accepted: June 15, 2020

\section{Высокорезультативные систель организации труда в российских и индийских Ит-колпаниях}

\section{Е. К. Завьялова, Д. Г. Кучеров, В. С. Цицова}

Институт «Высшая школа менеджмента», Санкт-Петербургский государственный университет, Россия

Настоящее исследование нацелено на изучение высокорезультативных систем организации труда в отрасли информационных технологий развивающихся рынков России и Индии. Это одна из ключевых тем в современном стратегическом управлении человеческими ресурсами. Исследование, основанное на опросе 132 компаний, выявило различия в практиках управления человеческими ресурсами ИТ-компаний России и Индии, которые формируют высокорезультативные системы организации труда, ориентированные на высокую вовлеченность и приверженность. Кроме того, результаты регрессионного анализа показали наличие различий во влиянии этих систем на результативность фирм. Выводы работы способствуют продолжению исследований данных систем организации труда в интеллектуально-емких фирмах на развивающихся рынках. 
Ключевые слова: высокорезультативные системы организации труда, высокорезультативные практики управления трудом, результативность, ИТ-компании, интеллектуально-емкие фирмы. JEL: M12, M54.

For citation: Zavyalova E. K., Kucherov D. G., Tsybova V. S. 2020. High-performance work systems in Russian and Indian IT companies. Russian Management Journal 18 (2): 235-254.

Статья поступила в редакцию 21 декабря 2019 г. Принята к публикации 15 июня 2020 г. 